University of Nebraska - Lincoln

DigitalCommons@University of Nebraska - Lincoln

Review of issues concerning the use of reproductive inhibitors, with particular emphasis on resolving human-wildlife conflicts in North America

\author{
Kathleen A. Fagerstone \\ USDA-APHIS-Wildlife Services \\ Lowell A. Miller \\ USDA-APHIS-Wildlife Services \\ Gary Killian \\ Pennsylvania State University \\ Christi A. Yoder \\ USDA-APHIS-Wildlife Services
}

Follow this and additional works at: https://digitalcommons.unl.edu/icwdm_usdanwrc

Part of the Environmental Sciences Commons

Fagerstone, Kathleen A.; Miller, Lowell A.; Killian, Gary; and Yoder, Christi A., "Review of issues concerning the use of reproductive inhibitors, with particular emphasis on resolving human-wildlife conflicts in North America" (2010). USDA Wildlife Services - Staff Publications. 895.

https://digitalcommons.unl.edu/icwdm_usdanwrc/895

This Article is brought to you for free and open access by the U.S. Department of Agriculture: Animal and Plant Health Inspection Service at DigitalCommons@University of Nebraska - Lincoln. It has been accepted for inclusion in USDA Wildlife Services - Staff Publications by an authorized administrator of DigitalCommons@University of Nebraska - Lincoln. 


\title{
Review of issues concerning the use of reproductive inhibitors, with particular emphasis on resolving human-wildlife conflicts in North America
}

\author{
Kathleen A. FAGERSTONE, ${ }^{1}$ Lowell A. MILLER, ${ }^{1}$ Gary KILLIAN ${ }^{2}$ and Christi A. YODER ${ }^{1}$ \\ ${ }^{1}$ US Department of Agriculture/Animal and Plant Health Inspection Service/Wildlife Services, National Wildlife Research Center, Fort \\ Collins and ${ }^{2}$ Almquist Research Center, Pennsylvania State University, University Park, USA
}

\begin{abstract}
This manuscript provides an overview of past wildlife contraception efforts and discusses the current state of research. Two fertility control agents, an avian reproductive inhibitor containing the active ingredient nicarbazin and an immunocontraceptive vaccine, have received regulatory approval with the Environmental Protection Agency and are commercially available in the USA. OvoControl G Contraceptive Bait for Canada Geese and Ovo Control for pigeons are delivered as oral baits. An injectable immunocontraceptive vaccine (GonaCon Immunocontraceptive Vaccine) was registered with the Environmental Protection Agency for use in female white-tailed deer in September 2009. An injectable product (GonaCon Immunocontraceptive Vaccine) is registered for use in female white-tailed deer. Both products are labeled for use in urban/suburban areas where these species are overabundant. Several other compounds are currently being tested for use in wildlife in the USA, Europe, Australia and New Zealand that could have promise in the future. The development and use of reproductive inhibitors for resolving human-wildlife conflicts will depend on a number of factors, including meeting the requirements of regulatory agencies for use in the environment and on the biological and economical feasibility of their use. Use will also be dependent on health and safety issues and on public acceptance of the techniques.
\end{abstract}

Key words: contraceptives, fertility control, registration, reproductive inhibitors, wildlife.

\section{INTRODUCTION}

Wild animals are valuable natural resources and vital components of a healthy ecosystem. Wildlife provides economic, recreational and aesthetic benefits and, to many people, the knowledge that wildlife exists is a positive

Correspondence: Kathleen A. Fagerstone, US Department of Agriculture/Animal and Plant Health Inspection Service/Wildlife Services, National Wildlife Research Center, 4101 LaPorte

Avenue, Fort Collins, CO 80521-2154, USA.

Email: kathleen.a.fagerstone@aphis.usda.gov benefit in itself. For most of the past century, federal and state wildlife conservation agencies in the USA and around the world have focused on increasing populations of many species of wildlife. In many cases, such as for the whitetailed deer Odocoileus virginianus (Zimmermann, 1780) and Canada geese Branta canadensis (Linnaeus, 1758) in the USA, the badger Meles meles (Linnaeus, 1758) in Great Britain, the fox Vulpes vulpes (Linnaeus, 1758) in Europe and the wallaby Macropus eugenii (Desmarest, 1817) in Australia, these conservation efforts have been extremely successful, to the point where these species are locally overabundant and cause either ecological damage or human-wildlife conflicts, including damage to agricultural 
commodities, disease transmission to humans, livestock or other valued wildlife, and safety issues such as wildlife aircraft strikes. Many of the problems associated with overabundant wildlife occur in suburban or urban areas where regulation of wildlife populations through conventional means such as hunting, translocation or culling has not been feasible, or is precluded because of regulations or public perceptions. The need for wildlife management is increasing as people continue to encroach upon natural habitats and human-wildlife conflicts become more frequent. At the same time, the public is becoming intolerant of perceived inhumane means of control. A growing interest in nonlethal methods for population control of nuisance or damaging wildlife species has fostered research in wildlife contraception. Because fertility control acts by reducing birth rates, rather than by increasing mortality rates, it is perceived by the public as being more humane and morally acceptable than conventional population control methods.

This manuscript provides an overview of issues relating to the use of contraceptive agents, particularly in North America, as a means of resolving human-wildlife conflicts. In the manuscript we discuss compounds currently and previously used to control fertility in wildlife; the regulatory pathways for gaining approval of contraceptive agents and their economic feasibility; health and safety concerns for use of contraceptives; and public perceptions on use of contraceptive agents. Many contentious issues have been raised regarding the use of infertility agents for managing wildlife populations (Bomford 1990). The following sections will address each of these issues. This paper focuses specifically on the USA, but includes references to Europe, New Zealand and Australia, both because of collaborative research on development of wildlife contraceptives and because of new initiatives in these countries to develop anti-fertility agents for the field control of vertebrate pests (Lapidge et al. 2007).

\section{REVIEW OF CURRENT TECHNOLOGY FOR WILDLIFE CONTRACEPTION}

\section{Steroids/hormones}

Chemical contraception through the use of synthetic steroids, estrogens and progestins was investigated widely during the 1960s and 1970s in many species (Fagerstone et al. 2002). More recently, androgens have also been tested for use in male rodents and wolves (Canis lupus) (Asa 1997). These steroid hormones act by interfering with ovulation or implantation of the egg in female animals or by impairing spermatogenesis in males. Unfortunately, none of the steroid compounds has gone beyond the testing stage in wildlife.

A potential use of steroids for contraception in wildlife involves the delivery of norgestomet (a progesterone approved by the Food and Drug Administration [FDA] for use in cattle for estrus synchronization) to black-tailed deer (Odocoileus hemionus) using a biobullet (Jacobsen et al. 1995; DeNicola et al. 1997a). In Jacobsen et al. (1995), the ten treated failed to exhibit estrous behavior during the fall rut and two treated bucks exhibited no sexual behavior for one year.

Lutalyse, produced by Upjohn (prostaglandin PGF2?), is used in feedlot cattle during the first 100 days of gestation to interfere with pregnancy. DeNicola et al. (1997b) and Waddell et al. (2001) reduced fertility in white-tailed deer (Odocoileus virginianus) by injecting Lutalyse. Levonorgestrel is the active component of the Norplant implant approved for human use as a contraceptive implant by the FDA (McCauley \& Geller 1992); it has been used in zoos but is not effective in deer (Plotka \& Seal 1989; White et al. 1994). Medroxyprogesterone acetate (Provera) has been used in zoos. Megestrol acetate is marketed in Europe as Ovarid and in the USA as Megace, and Ovaban and is sometimes used as a contraceptive in domestic dogs (Canis familiaris Linnaeus, 1758) and cats (Felis catus Linnaeus, 1758), but it showed only weak effects on feral cats in McDonald (1980) and no effect on white-tailed deer in Matschke (1977). Melengestrol acetate (MGA) is approved by the FDA for use in cattle as a daily administration (Zimbelman \& Smith 1966) for suppression or synchronization of estrus, increased weight gain and improved feed efficiency (Bennett 1993). It has been shown to inhibit reproduction in white-tailed deer when ingested daily (Roughton 1979) or implanted (Bell \& Peterle 1975; Plotka \& Seal 1989). MGA implants have been used by zoos for approximately 20 years, but recent findings of uterine pathology in felids have raised concerns about its use (Kazensky et al. 1998).

Some steroid hormones target males rather than females (Asa 1997). Bisdiamine is a compound that selectively interferes with spermatogenesis but not testosterone production. When administered in ground meat daily to gray wolves it suppressed spermatogenesis without affecting mating behavior (Asa et al. 1996). Indenopyridine also blocks sperm production; it has been tested in rodents and dogs (Chang et al. 2002). Alpha-chlorohydrin (Epibloc), a male chemosterilant, was approved by the Environmental Protection Agency (EPA) for use as a rat control agent in 1982 (Bowerman \& Brooks 1971; Ericsson 
1982; Andrews \& Belknap 1983) but is no longer marketed. At low doses it caused temporary sterilization, with time to recovery of fertility dependent on dose. A single high dose caused permanent sterility but showed toxic effects. In addition, rats (Rattus spp.) have a promiscuous mating system, so targeting only male rats offered little promise as a population control technique.

Despite considerable effort, steroid hormones have not been used successfully to inhibit reproduction in overabundant animals. Although steroids can be fed orally or implanted, they are effective for only a short period and need repetitive applications, making them costly and impractical in most field situations. Some steroids, such as diethylstilbestrol (DES), persist in tissue and in the food chain, making them unsatisfactory from an environmental point of view. They can also have deleterious health effects on treated animals. For example, DES was found to be a teratogen when given to pregnant women.

\section{Chemicals that cause premature ovarian}

\section{failure (senescence)}

In most species of mammals, the female is born with a finite number of primordial follicles. The number of follicles that are ovulated is small compared with the total number of primordial follicles present at birth; most follicles do not develop fully, but undergo atresia (cell death) at various development stages. Follicular atresia occurs continuously in the ovary after birth until the supply of follicles is depleted and ovarian failure (menopause in women) or sterilization occurs. Scientists are currently looking into techniques that will induce early ovarian failure as a tool for reproductive control of pest animals.

One chemical that has been shown to destroy oocytes contained in primordial and primary follicles is 4vinylcyclohexene diepoxide (VCD). The compound 4vinylcyclohexene $(\mathrm{VCH})$ is used in the synthesis of rubber products, insecticides, flame retardants, antioxidants and plasticizers. In vivo, VCH is metabolized to VCD by cytochrome P450-catalyzed epoxidation (Hu et al. 2006). Medical researchers investigating the mechanisms of premature ovarian failure and menopause use VCD to induce these conditions in rodent models. Repeated exposure to VCD selectively destroys primordial and primary follicles by increasing the rate of follicular atresia, ultimately depleting the ovary of most of the existing follicles and causing ovarian senescence (Mayer et al. 2004; Hue et al. 2006). This leads to a hormonal profile comparable to a female in menopause, characterized by high luteinizing hormone (LH) and follicle stimulating hormone (FSH) concentrations and decreased estradiol concentrations.
Mayer et al. (2004) report that repeated exposure of VCD depletes small pre-antral (primordial and primary) ovarian follicles, resulting in follicle depletion and ovarian failure. Ten days of VCD treatment appears to be the minimum number of days required to initiate ovotoxic effects; approximately half the follicle supply is depleted after 15 days of treatment, and almost all follicles are depleted after 30 days of treatment (Springer et al. 1996; Mayer et al. 2004; Hu et al. 2006). This compound could, therefore, be used as a permanent sterilant for selected wildlife species when given in repeated doses. Mayer (2006) has begun looking at VCD as an injectable contraceptive for use in dogs (C.familiarus) and cats (Felis domesticus).

\section{Avian contraceptives}

Interfering with egg laying or the hatchability of the egg can be used to reduce reproductive capacity in birds. Egg addling, including shaking or oiling the eggs in the nest, effectively reduces egg hatchability (Pochop et al. 1998). Egg oiling with corn oil is allowed by the EPA under the Federal Insecticide, Fungicide and Rodenticide Act (Revised October 1988) 25b exemption for natural products, and is being used to reduce reproduction in Canada geese (B. canadensis) and gulls (Larus spp.). However, this method is labor intensive and probably useful only in small areas.

Ornitrol (DiazaCon) is a cholesterol mimic that has a chemical structure similar to cholesterol (Miller \& Fagerstone 2000). It inhibits formation of pregnenolone, the parent compound of steroid hormones, preventing formation of testosterone and progesterone. DiazaCon persists in the body, so its reproductive inhibition effects can last up to several months. It was registered in the late 1960s with the EPA as the oral pigeon (Columba livia Gmelin, 1789) reproductive inhibitor Ornitrol, but the registration was cancelled in 1993. Although the drug was effective in reducing egg laying and egg hatchability (Woulfe 1968), the pigeon is a year-round breeder and long-term use of the compound became expensive. In addition, long-term ingestion of this product at high levels might have undesirable health effects on the birds (Lofts et al. 1968) because cholesterol is necessary for a range of key processes within the body as well as the production of reproductive hormones. In recent tests, the compound was found to be effective in reducing egg laying, egg fertility and egg hatchability for 2-4 months in coturnix quail Coturnix coturnix (Linnaeus, 1758) after feeding it for 10-14 days (Yoder 2000; Yoder et al. 2004). It was effective on both sexes, with testosterone declining in treated males and progesterone declining in treated females (Yoder 
et al. 2004). DiazaCon might prove useful in controlling the reproduction of seasonally breeding bird species when fed just prior to breeding in the spring. It is being tested in the monk parakeet Myiopsitta monachus (Boddaert, 1783) in Florida, where the birds nest on power stations and power poles, causing power outages (Avery et al. 2006). DiazaCon is not species-specific, and could potentially be effective in mammalian as well as avian species.

Conjugated linoleic acid (CLA) has been tested as an avian infertility agent for use in cold climates. It is used as a feed additive to increase weight gain and feed efficiency in broiler chickens (Chin et al. 1994). When fed to laying chickens, CLA reduces hatchability by causing solidification of the yolk at refrigerator temperatures (Cooney 1995). In theory, when the clutch is being laid in the spring, the bird does not incubate the nest until the clutch is complete. As the temperature drops during the night, the yolk of unincubated eggs from CLA-fed birds solidifies, interfering with hatchability. CLA is specific to avian species and its effect is reversible but it needs to be fed for 10 or more days. In a study by Aydin \& Cook (2006), CLA increased embryonic mortality in pigeon eggs to $100 \%$ after 10 weeks of feeding. However, it was ineffective in a limited field trial with Canada geese (S. Craven, University of Wisconsin, personal communication).

Nicarbazin (NCZ) is a compound approved by the FDA for control of coccidiosis in broiler chickens; if accidentally fed to breeder or layer hens, $\mathrm{NCZ}$ causes reduction in hatchability and egg laying due to increased permeability of the membrane between the egg white and egg yolk, which destroys the conditions necessary for development of the embryo (Jones et al. 1990). The ideal dose rate allows the female bird to lay eggs and sit on them, but prevents hatching. Advantages of nicarbazin are that it is specific to egg layers, it is cleared from the body within approximately $48 \mathrm{~h}$ and the infertility effect is reversible. A disadvantage of the compound is that it has to be fed continuously prior to and during egg laying. Nicarbazin was tested by the National Wildlife Research Center (NWRC) and subsequently registered by Innolytics LLC as a reproductive inhibitor for use in Canada geese in 2005 and for use in pigeons in 2007. Field studies show that use of Ovocontrol $\mathrm{G}$ immediately prior to and during the breeding season can reduce numbers and hatchability of eggs laid by Canada geese, thereby reducing recruitment of goslings into problem resident populations (Bynum et al. 2005, 2007)

\section{Immunocontraception vaccines}

Much recent research has gone into the development of immunocontraceptive vaccines, which use the animal's immune system to produce antibodies against gamete proteins, reproductive hormones and other proteins essential for reproduction. The antibodies interfere with the biological activity of the reproductive agents (Talwar \& Gaur 1987); the vaccines can be effective for $1-4$ years or longer (Turner \& Kirkpatrick 1991; Miller et al. 2000b).

\section{Zona pellucida vaccines}

The zona pellucida (ZP) is a glycoprotein layer located on the outer surface of the egg. Antibodies to ZP result in infertility either by blocking sperm from penetrating the ZP layer or by interfering with egg maturation within the follicle (Dunbar \& Schwoebel 1988). The porcine ZP (PZP) vaccine includes both the PZP protein from the pig ovary and an adjuvant (an additive to increase the immune response). PZP has been successfully tested in numerous species, including dogs (Mahi-Brown et al. 1985), baboons (Dunbar 1989), coyotes (Canis latrans) (Miller 1995; DeLiberto et al. 1998; Miller et al. 2006), burros (Equus asinus) (Turner et al. 1996), wild horses (Equus caballus) (Kirkpatrick et al. 1990; Garrott et al. 1992; Turner et al. 2000, 2002, 2007; Killian et al. 2004, 2006b) and whitetailed deer (Turner et al. 1992, 1997; Miller et al. 2000a,b, 2001; Fraker et al. 2002; Miller \& Killian 2002). PZP is not effective in cats (Jewgenow et al. 2000) or rodents (Drell et al. 1984). Injecting with an initial and a booster dose of PZP vaccine has caused infertility in deer and horses for several years (Miller et al. 2000b). A vaccine (SpayVac) developed by ImmunoVaccine Technologies and using an adjuvant developed at the National Wildlife Research Center (Adjuvac) has been effective in white-tailed deer and horses for up to four years after a single shot (Fraker et al. 2002; Killian et al. 2004, 2006b). The single-shot is a major breakthrough because animals only need to be handled once. PZP vaccines are not species-specific and are effective in reducing fertility in most mammals tested. A disadvantage of PZP in deer is that it is associated with multiple estrous cycles in does, which could result in late season births if antibody titers drop below a critical threshold late in the breeding season.

\section{Immunocontraception with gonadotropin-releasing hormone vaccines}

Gonadotropin-releasing hormone (GnRH) immunocontraceptive vaccines take advantage of the role played by $\mathrm{GnRH}$ in regulating mammalian reproduction. GnRH controls steroidogenesis and gametogenesis by stimulating the release of gonadotropins from the pituitary, triggering the cascade of reproductive hormones that lead 
to ovulation. An immunocontraceptive vaccine developed by the United States Department of Agriculture's (USDA) NWRC shows great potential as a contraceptive agent for deer and other mammals. GonaCon Immunocontraceptive Vaccine (NWRC, Fort Collins, Colorado, USA) can be administered as a single injection that suppresses reproduction in treated animals of both sexes (Miller et al. 2004b). GonaCon Vaccine causes immunization against GnRH by stimulating the production of antibodies that neutralize $\mathrm{GnRH}$ in the vasculature between the hypothalamus and the anterior pituitary gland (Adams \& Adams 1992; Herbert $\&$ Trigg 2005). As a result, secretion of LH and FSH by the anterior pituitary is suppressed. In females, follicular development, ovulation and estrus are inhibited. In males, testosterone levels are reduced; testicular size and aggressive behavior decrease significantly, and no interest is shown in estrous females (Miller et al. 2004b). As long as antibody titers to native GnRH are sufficiently elevated, reproductive behavior will be suppressed and the contraceptive effect will last in both sexes (Miller et al. 2004b). GonaCon has induced contraception in many mammalian species, including California ground squirrels (Spermophilus beecheyi) (Nash et al. 2004), captive Norway rats (Rattus norvegicus) (Miller et al. 1997), domestic cats (F. catus) (Levy et al. 2004), domestic and feral swine (Sus scrofa) (Killian et al. 2003, 2006c; Miller et al. 2003), wild horses (Equus caballus) (Killian et al. 2004, 2006a), bison (Bison bison) (Miller et al. 2004a) and white-tailed deer (Miller et al. 2000).

Gonadotropin-releasing hormone is a small hormone that is a weak antigen due to its low molecular weight and its being a "self" hormone (Herbert \& Trigg 2005). GnRH is made immunogenic by conjugating it to a large, nonself, hemocyanin protein harvested from marine mollusks (Miller et al. 2003, 2004b). An adjuvant is used in conjunction with the vaccine to achieve an immune response sufficient to provide contraception. The adjuvant used in GonaCon vaccine was developed at NWRC and consists of a modified USDA-approved vaccine for Johne's disease called Mycopar (Fort Dodge Animal Health, Fort Dodge, Iowa, USA). Mycopar is approved for use in food animals and, therefore, does not raise concerns regarding the consumption of GonaCon-treated deer by humans or by other non-target species (Miller et al. 2004b).

The USDA submitted an application to the US EPA in January of 2008 for registration of GonaCon as a contraceptive agent for adult female white-tailed deer. GonaCon was approved for registration in September 2009 as a "Restricted Use" product, for use by USDA Wildlife Services or state wildlife management agency personnel or persons working under their authority. GonaCon users will also need to follow state authorization processes.

\section{Sperm antibody vaccines}

Sperm vaccines could potentially disrupt fertility in females as well as in males. Sperm head glycoproteins that bind to $\mathrm{ZP}$ have been identified. If these glycoproteins are used as vaccines, antibodies are produced in the female and are available to bind to sperm present in the oviduct, preventing conception by blocking the sperm from binding to the ZP surrounding the egg. Sperm protein immunocontraception is being investigated for contraception in the red fox (Vulpes vulpes), rabbit (Oryctolagus cunniculs) and tammar wallaby (Macropus eugenii) in Australia(Tyndale-Biscoe 1991; Morell 1993; Bradley 1997; Asquith et al. 2006). Although not yet tested in wildlife species, contraceptive vaccines targeting sperm DNA being evaluated in laboratory rodents show some promise for future development of a sperm directed vaccine (Jagadish et al. 2006; Naz 2006).

\section{Gonadotropin-releasing hormone agonist}

Superactive analogs of the GnRH hormone (agonists), such as leuprolide, have been synthesized that are many times more active than naturally occurring GnRH and act to suppress the release of reproductive hormones. Longterm treatment with a GnRH agonist has been shown to prevent ovulation by decreasing GnRH receptors on gonadotropes, reducing receptor sensitivity to GnRH, decreasing pituitary LH content and by suppressing pulsatile secretion of LH and FSH (Nett et al. 1981; Aspden et al. 1996; D'Occhio et al. 1996). These conditions persist as long as the agonist is present, but once treatments are terminated, normal ovarian function is restored (Bergfeld et al. 1996). Continuous treatment with a GnRH agonist inhibits ovulation in females of several species, including dogs, cattle, sheep, horses, monkeys, deer and elk (Cervus elaphus) (see Fagerstone et al. 2002). Agonists of GnRH have been used in domestic ungulates for controlling ovarian activity, gonadal steroidogeneis and reproduction (D'Occhio et al. 2002). However, their use in wild ungulates has been limited (Becker \& Kautz 1995; Brown \& Jochle 2001), as a result, in part, to the need for continuous delivery of a therapeutic dose for the duration of the desired period of infertility. Recently, the impracticality of this approach for wildlife applications has been largely overcome by the development of long-acting biodegradable implants that can deliver a sustained release of GnRH agonist over a predetermined period of time (Ravivarapu et al. 2000; Trigg \& Doyle 2001). Controlled release, GnRH 
agonist formulation (ATRIGEL, Atrix Laboratories, Fort Collins, Colorado, USA) has been shown to effectively suppress reproductive function in captive and free-ranging elk, and captive mule deer $(O$. hemionus) for one breeding season, without significant physiological or behavioral side effects (Baker et al. 2002, 2003, 2004). Results of recent experiments with captive elk indicate that this leuprolide formulation is equally effective in suppressing reproduction when administered either subcutaneously or with a syringe dart, thus enhancing the efficacy of management applications (Baker et al. 2005).

\section{Gonadotropin releasing hormone: toxin conjugate}

For wild ungulates, a single-dose long-acting contraceptive offers a promising technology for population management (Hobbs et al. 2000). A new contraceptive approach being studied involves linking synthetic analogs of $\mathrm{GnRH}$ to cytotoxins. By coupling a superactive analog of $\mathrm{GnRH}$ to a cytotoxin, it is possible to specifically target that toxin to LH-secreting and FSH-secreting cells in the anterior pituitary gland, potentially inducing permanent sterility in both sexes. Preliminary results in female mule deer indicate that a GnRH-toxin conjugate will suppress LH secretion for up to 6 months (Baker et al. 1999).

There are a number of complex technical, biological, economic and legal issues that need to be addressed before any of the reproductive inhibitors discussed above can be used widely in field situations. One of the most important of those considerations is whether the reproductive inhibitors can be approved for use by regulatory agencies.

\section{REGULATION OF WILDLIFE CONTRACEPTION DRUGS, WITH EMPHASIS ON THE USA}

Environmental protection agencies throughout the world are encouraging the replacement of persistent or unpopular vertebrate pesticides with more humane alternative toxicants or nonlethal means of control (Eason et al. 2010). In particular, the USA, New Zealand and Australia are undertaking collaborative research and new initiatives to develop more humane and species-targeted toxins and anti-fertility agents for the field control of vertebrate pests (Lapidge et al. 2007). The agencies responsible for the regulation of reproductive inhibitors for wildlife include the Australian Pesticide and Veterinary Medicine Authority, the Environmental Risk Management Au- thority in New Zealand and the EPA in the USA. Calls have been made for greater collaboration and harmonization in the registration of pesticides and, in particular, for vertebrate pesticides in these countries (Lapidge et al. 2007). However, because the USA currently has the only registered reproductive inhibitors for wildlife, this review will focus on the regulatory process in the USA. Between 1996 and 2006, the regulatory agency responsible for wildlife contraceptives in the USA was the FDA, Center for Veterinary Medicine (CVM). Working under this premise, the NWRC progressed toward fulfilling the FDA's regulatory requirements by obtaining Investigational New Animal Drug (INAD) numbers for several contraceptives; these INADs allowed research to be conducted on field efficacy and target animal safety. During this time, it became clear that wildlife contraceptives were incompatible with the FDA's regulatory process. In response, the FDA and the EPA negotiated an agreement on contraceptive uses. Beginning in 2006, the EPA assumed regulatory authority over contraceptives used for wildlife and feral animals. The CVM will retain authority over all uses in captive animals, including livestock, companion animals and zoo animals.

The EPA is responsible for regulating pesticides under the Federal Insecticide, Fungicide and Rodenticide Act. Registration of a contraceptive "pesticide" by the EPA requires submission of a series of studies on product chemistry, toxicity, non-target hazards, environmental fate and efficacy. The EPA registration process can take several years. The EPA has fewer registration requirements for an injectable immunocontraceptive vaccine than for an oral product because an injectable product poses little risk of negative impact to air, water and soil, or to nontarget animals. There are currently two fertility control agents for wildlife that have received approval by the EPA. OvoControl G, an orally-delivered product, was recently registered by Innolytics, LLC (working cooperatively with the NWRC), for managing Canada geese and pigeons and is commercially available in the USA. USDA/Animal and Plant Health Inspection Service received a registration for the single-shot GonaCon Immunocontraceptive Vaccine in September, 2009 for managing white-tailed deer in areas where traditional management techniques, such as sport hunting, cannot be employed.

The two contraceptive "pesticides" currently registered are considered restricted use products and may be used only by certified pesticide applicators. The certified applicator legend has been required for several reasons: (i) training may be necessary to ensure the humane treatment of the animals (i.e. knowledge of darting, trapping 
Table 1 Estimated relative efficiency of reproductive and lethal control based on numbers remaining after three years from an initially stable population of 1000 individuals in which reproductive or survival rate is reduced annually by $50 \%$ (using population models presented in Dolbeer 1998)

\begin{tabular}{|c|c|c|c|c|c|}
\hline & \multicolumn{3}{|c|}{ Number remaining after 3 years } & \multicolumn{2}{|c|}{$\begin{array}{l}\text { Relative efficiency }{ }^{\dagger} \text { of lethal } \\
\text { to reproductive control } \\
\text { (eproductive control/lethal } \\
\text { control) after } 3 \text { years }\end{array}$} \\
\hline & $\begin{array}{l}\text { Reproductive } \\
\text { control }\end{array}$ & \multirow{2}{*}{$\begin{array}{l}\text { Lethal } \\
\text { control } \\
>\text { Age } 0^{*}\end{array}$} & \multirow[b]{2}{*}{$>$ Age $1^{\S}$} & \multirow[b]{2}{*}{$>$ Age $0^{\ddagger}$} & \multirow[b]{2}{*}{$>$ Age $1^{\S}$} \\
\hline Species & & & & & \\
\hline Fruit bat (Pteropus giganteus) & 731 & 125 & 191 & 5.8 & 3.8 \\
\hline Laughing gull (Larus atricilla) & 720 & 125 & 180 & 5.8 & 4.0 \\
\hline Double crested cormorant (Phalacrocorax auritus) & 673 & 125 & 183 & 5.4 & 3.7 \\
\hline White-tailed deer & 639 & 125 & 212 & 5.1 & 3.0 \\
\hline Beaver (Castor canadensis) & 624 & 125 & 199 & 5.0 & 3.1 \\
\hline Canada goose & 607 & 125 & 193 & 4.9 & 3.1 \\
\hline Coyote & 486 & 125 & 264 & 3.9 & 1.8 \\
\hline Common grackle (Quiscalus quiscala) & 460 & 125 & 349 & 3.7 & 1.7 \\
\hline Brown-headed cowbird (Molothrus ater) & 338 & 125 & 462 & 2.7 & 1.3 \\
\hline Red-billed quelea (Quelea quelea) & 368 & 125 & 421 & 2.9 & 0.7 \\
\hline Black rat (Rattus rattus) & $97^{\natural}(406)^{\dagger \dagger}$ & $307^{\S}$ & $675^{\natural}$ & $0.3^{\S}$ & $0.6^{4}$ \\
\hline
\end{tabular}

${ }^{\dagger}$ Efficiency ratios presented are specific to population status after three years and will increase during additional years of treatment. ${ }^{\star}$ Survival

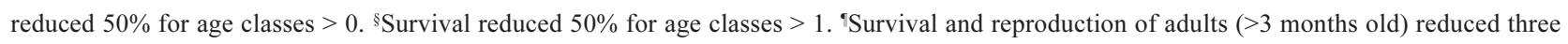
times per year. ${ }^{\dagger}$ Survival and reproduction of adults ( $>3$ months old) reduced once per year.

and other capture methods); (ii) there may be a potential hazard to the person administering some products if they are not handled properly; and (iii) the restriction minimizes potential for inappropriate use or non-target hazards. Because wildlife are owned by the public in the USA and managed by federal and/or state wildlife agencies, these agencies need to be consulted regarding use.

\section{BIOLOGICALAND ECONOMIC FEASIBILITY OF CONTRACEPTIVES}

In addition to regulatory requirements, an important consideration for development of reproductive inhibitors is the practicality of their use for free-ranging wildlife. Whether fertility control is biologically feasible or economically advantageous when compared to lethal control for a particular species and population depends on a number of parameters (Curtis et al. 1997; Nielsen et al. 1997), including whether the population is "open" or "closed," population numbers, sex ratios, age structure and esti- mated rate of increase and mortality of the concerned species. Dolbeer (1998) uses population models to compare the relative efficiency (i.e. percentage decline in population size relative to number of animals sterilized or removed) of reproductive control and lethal control in managing wildlife populations. The predicted relative efficiencies of lethal and reproductive control for various wildlife species (Table 1) can be generalized based on adult survival rate and age at which animals reproduce. Whether lethal control is more efficient than contraception depends on the age at first reproduction in combination with the adult survival rate. For animals that first breed at one or two years of age, lethal control is only more efficient than contraception for reducing populations when adult survival rates exceed 0.56 and 0.23 , respectively. However, for animals that first breed at three years of age, lethal control will always be more efficient than contraception for reducing populations, regardless of the adult survival rate (Dolbeer 1998). In general, this means that reproductive control will be most effective in managing species 
such as rodents or some bird species with high reproductive rates and low survival rates. Knipling and McGuire's (1972) theoretical model demonstrates that if $70 \%$ of rats can be sterilized for three generations (one year), the population will be almost eliminated, whereas a similar effort using lethal control allows the population to rebound to its original size. Reproductive control will typically be less efficient than lethal control in managing populations for larger species such as deer, coyotes and Canada geese that do not typically reproduce until 2-4 years of age and have smaller litter or clutch sizes than most rodents and small birds. Therefore, for long-lived wildlife species like deer, it may be prudent to reduce the population herd to a desired number by some other management technique before applying fertility control to stabilize herd growth (Nielsen et al. 1997).

Hobbs et al. (2000) produce a series of models examining fertility control of ungulates and conclude that $>50 \%$ of fertile females need to be maintained infertile to achieve reductions in ungulate numbers. When adult survival is high (>95\%), Hobbs et al. assume that $60 \%$ of breeding females need to be infertile to achieve a population reduction. Garrott (1995) and McCullough (1996) also estimate that $60-80 \%$ of adult females would require effective annual contraceptive treatment to stabilize populations with a yearly (rather than a longer-lasting) treatment. Seagle and Close (1996) suggest that sterilization of $<50 \%$ of does would maintain population size over a 30 -year period, whereas it would take $5-10$ years to see a significant population decline with sterilization of $>50 \%$ of does in a closed population. Merrill et al. (2006) determine that in a closed population, permanent fertility control could begin to reduce a population after $2-3$ years, and a population reduction of approximately $60 \%$ could be achieved within 10 years if approximately $30-45 \%$ of the animals were captured annually. Hobbs et al. (2000) note that fertility control using long-lived agents could be more efficient than culling in regulating ungulate numbers, and that when contraception persists for the lifetime of the animal, models predict that, in most cases, the effort required to regulate a population at a specified density using fertility control would be less than the effort required for culling.

\section{Economic practicality}

In addition to being biologically feasible, infertility agents will need to be economically practical to use. Economic practicality involves the cost of development and authorization of the contraceptive, as well as costs of treatment, including labor, equipment and contraceptive. Field use of contraceptives can be costly. Development of single-shot GnRH and PZP immunocontraception vac- cines has made their use more economically and logistically feasible than when multiple shots of vaccines were required; however, vaccines are injectable only by hand or using a biobullet or dart gun. Capture and injection by hand is preferred because animals can be individually marked when they are injected. Costs to capture and inject deer have been estimated to be greater than $\$ 250$ for each deer marked (Curtis et al. 1997). Hobbs et al. (2000) state that the expense of fertility control will not compete favorably with the revenue that could be provided by licensed hunters. They suggest that the greatest efficiency can be obtained by combining initial culling with contraceptive treatment using multi-year fertility control agents. Oral delivery would be a practical, cost-effective means to deliver contraceptive vaccines to some populations of freeroaming animals (Miller 1997). However, oral delivery of vaccines is a difficult technology and is not expected to be developed soon.

Chemical contraceptives such as steroids, DiazaCon and nicarbazin (OvoControl G), can be delivered orally in baits but it can be difficult to get adequate bait consumption. For example, OvoControl G (used to reduce egg hatchability) must be fed to Canada geese daily for the entire egg laying period. DiazaCon also must be fed to animals several times over a 10-14 day period. These compounds must also be used over multiple years to reduce populations.

\section{HEALTH AND SAFETY ISSUES}

When the reproductive inhibitors discussed previously are used for long periods of time or are placed out into the environment, their use raises questions regarding the health and safety of: (i) target animals; (ii) non-target animals; and (iii) humans. Fagerstone et al. (2002) summarize the potential health effects of contraceptive agents. Health data on target animals have been gathered for the immunocontraceptive products PZP and GnRH. In longterm studies involving PZP and GnRH on white-tailed deer (Miller et al. 2000b,c; Miller \& Killian 2000), animals were observed for effects on reproduction, behavior and animal health. GnRH vaccine treatments of white-tailed deer led to reduced progesterone concentrations, altered estrus behavior, contraception, failure to maintain pregnancy following conception, and reduced fawning rates (Miller et al. 2000). Infertility lasted up to two years without a booster injection. GnRH-immunized bucks demonstrated no sexual activity when paired with control does. Depending on the immunization schedule, antlers either dropped early or remained in velvet. Necropsies of recently vaccinated deer showed that ovaries looked normal. 
A comprehensive study of toxicity and safety of use of GonCon was conducted (Killian et al. 2006c) as part of the package required by the EPA to register GonCon for use in white-tailed deer. In the 20 -week study, some does were given a single injection of GonCon and some were given three injections of GonaCon at two-week intervals per dose. Blood was assayed for $\mathrm{LH}$, testosterone, progesterone and anti-GnRH titers. In addition, hematology and blood chemistry were checked, and the general health of each doe was observed. At week 20, deer were killed and evaluated at necropsy by veterinary pathologists, and samples of tissues were taken for histology. There were no significant contraindications or toxic effects associated with GonaCon.

Data on health and behavioral effects related to PZP (Fagerstone et al. 2002) are available from both limited field applications (Turner et al. 1997; Warren et al. 1997; McShea et al. 1997) and from long-term studies (Miller et al. 2000c, 2001). A nine-year study of PZP-injected deer at Pennsylvania State University showed that vaccinated deer returned to fertility within 4-7 years after vaccinations ceased (Miller et al. 2000c). A long-term blood chemistry survey study on PZP-immunized deer found no statistically significant health changes in vaccinated deer (Miller et al. 2001). Over a four-year period, the health of control and treated deer were compared using measurements of body weight, serum cholesterol and blood serum chemistry profiles. No significant differences were found, suggesting that the health of the PZP-treated deer was not affected by long-term immunocontraceptive treatment (Miller et al. 2001). However, the PZP vaccine has been shown to increase the number of times a doe comes into estrus (estrus was occasionally extended into February for white-tailed deer), thereby prolonging the breeding season and potentially resulting in late summer or autumn births (Killian \& Miller 2000; Miller \& Killian 2000). In Northern climates, fawns are typically born in spring and early summer, grow rapidly during the summer and accumulate fat reserves to draw upon during the winter when sources of adequate nutrition are minimal. Smaller late fawns lack sufficient time to prepare adequately for winter and, consequently, have a poorer body condition, reduced ability to deal with snow and colder temperatures and reduced ability to evade predators.

Nicarbazin has been used by the poultry industry in numerous countries for 45 years. It has no effects in mammal species and is safe for both target and non-target bird species, even when administered at much higher doses than needed to cause the contraceptive effect (Wildlife Services 2004; Bynum et al. 2005). DiazaCon, as a choles- terol inhibitor, could cause health effects in either target or non-target species if fed for extended periods (Sachs \& Wolfmann 1965; Yoder et al. 2004). Trials with target species to establish appropriate dosages need to be conducted to minimize the risk of birds receiving a toxic dose.

In addition to being safe for target animals, contraceptives should not have adverse effects on non-target animals. Because technology is not currently available to make infertility agents species-specific, delivery systems should be developed to limit effects on non-target species. Delivery mechanisms such as injection, darting or implanting require direct contact with animals and will not affect non-target species. Use of oral bait delivery systems offers a way to treat larger, free-roaming populations at lower cost, but there is increased risk of unintentional treatment of non-target species. Therefore, the delivery system for contraceptive baits should be designed to exclude most non-targets. For example, an elevated bait station could be designed to allow a white-tailed deer doe to feed but exclude some non-target species.

Contraceptives used on huntable species of wildlife pose an additional safety consideration: safety to humans who may consume them. This risk is addressed by regulatory requirements of approval for drugs or pesticides. For compounds that accumulate in body tissue and could have secondary effects, such as some of the steroid contraceptives, FDA or EPA approval would not be granted for use in food animals such as deer and Canada geese without adequate data on chemical withdrawal times. Immunocontraception vaccines provide few risks for consumptive use of dosed wildlife; the antibodies that prevent reproduction are only one of millions of other antibodies present in animals, all of which are harmless to the organism that digests them, like any other proteinaceous food consisting of amino acids. Two infertility agents being researched for birds (nicarbazin and CLA) are already authorized by the FDA for use in broiler chickens and have low risk to humans. The third compound potentially proposed for birds, DiazaCon, was initially designed to be given to humans to lower serum cholesterol levels and, therefore, should present minimal hazard for human consumption at levels that would be potentially present in animal tissues.

\section{PUBLIC ATTITUDES TOWARDS WILDLIFE FERTILITY CONTROL AGENTS}

In addition to the biological, economic and legal issues 
that have to be considered before wildlife fertility agents can be used in field situations, these fertility agents need to be socially acceptable for that particular use. Traditionally, hunting, trapping or toxicants have been the primary management tools for controlling wildlife populations. In the USA, hunting has been the most important tool for managing most overabundant game populations. Many wildlife agencies and biologists have been reluctant to acknowledge the potential applicability of fertility control for managing wildlife populations (Warren 1995), in part because contraceptives have been publicized as replacements for sport hunting. A survey of 134 state, regional and national agencies and organizations in the USA (Sanborn et al. 1994) found that only 9\% of state wildlife agencies had an established policy on wildlife contraception, compared to $39 \%$ of 54 environmental and animal activist groups.

In large, free-ranging game populations, traditional methods of population reduction will still need to be applied because the cost and difficulty of delivery of contraceptive techniques would preclude their use. However, during the past 20 years, as farmlands and open habitats have been converted to suburban land uses, changes in wildlife distributions and density have increased the frequency of human-wildlife interactions in urban-suburban areas and parks where public hunting or trapping are not permitted by law. Local residents often experience conflicts with wildlife; many of these residents are opposed to lethal control of wildlife and support the development and use of nonlethal techniques such as contraception. Wildlife management agencies must be responsive to these suburban/urban stakeholders as well as to traditional ones. Achieving effective, humane and environmentally sensitive management of wildlife is of increasing concern to conservation biologists, wildlife managers, policy-makers and the general public. Therefore, researchers are seeking alternative means to manage wildlife, including use of contraceptives, and wildlife management agencies might be forced by the public to consider the costs and benefits of using contraception for managing wildlife populations.

Toxicants and trapping have always been relied upon heavily to control populations of non-native wildlife, such as the brush-tail possum (Trichosurus vulpecula) in New Zealand, the red fox in Australia and Germany, and the gray squirrel (Sciurus carolinensis) in Great Britain and Italy.

Surveys have shown that the public, particularly urban-suburban dwellers, are receptive to wildlife control in general and to the use of reproductive inhibitors in particular (Barr et al. 2002; Konig 2008). Although lethal control methods are currently used most frequently for controlling non-native wildlife, the public is increasingly more amenable to nonlethal control measures, such as livetrapping and contraception (Barr et al. 2002), and there is increasing public antipathy towards lethal methods of control. An example is the grey squirrel, which was introduced to Britain from North America in the late 1800s (Middleton 1930). Gray squirrels compete with native red squirrels (Sciurus vulgaris) and have replaced them throughout much of Britain (Barr et al. 2002). Despite their negative impact on red squirrel populations, gray squirrels are generally well liked by the public, who enjoy watching them. Toxicants are not publicly acceptable and translocation is not an option because, as an introduced species, gray squirrels may not be released after trapping. Contraception offers a potential nonlethal option for reducing the rate of spread of the gray squirrel.

Although currently available contraceptive techniques can sometimes be uneconomical for practical implementation, even in small localized populations of game species such as deer, they can be combined effectively with other management techniques in an integrated pest management approach. In these instances, a practical use for contraceptive products would be to maintain a wildlife population at a desired level after reduction of the population by other means.

\section{SUMMARY}

Currently, two oral contraceptive products (Ovocontrol $\mathrm{G}$ for use to manage resident Canada geese, and Ovocontrol P to manage pigeons) are available for commercial use in the USA. In addition, the injectable immunocontraceptive GonaCon has been registered in the USA for use in white-tailed deer. Other chemicals and vaccines are in various stages of development and testing by various agencies and organizations in the USA, Europe, Australia, New Zealand and elsewhere.

There are several factors that will determine when and where contraceptives will be useful for managing overabundant wildlife. The biological feasibility of using contraceptives to manage wildlife populations depends on the age at first reproduction and the adult survival rate. For animals that first breed at one or two years of age, either contraception or lethal control can be more efficient depending on the adult survival rate. However, for animals that first breed at three years of age, lethal control will be more efficient than contraception for reducing populations, regardless of the adult survival rate. This means that reproductive control will be most effective in managing species such as rodents or some bird species 
with high reproductive rates and low survival rates. For long-lived wildlife species like deer, it may be prudent to reduce the population herd to a desired number by some other management technique before applying fertility control to stabilize herd growth.

In addition to being biologically feasible, infertility agents will need to be economically practical. The cost of development and authorization of the contraceptive, as well as costs of treatment, including labor, equipment and contraceptive must be taken into account. Contraceptives also need to be evaluated for health effects: are they safe for the target animals, for non-target animals, and for humans? The regulatory agencies that register contraceptives for use play a large role in ensuring that wildlife and human health and safety are considered. In addition, because currently available infertility agents are not species-specific, delivery systems need to be developed to limit effects on non-target species. Delivery mechanisms such as injection require direct contact with animals and will not affect non-target species, but use of oral bait delivery systems should be designed to exclude most nontargets. Contraceptives used on huntable species of wildlife pose a potential safety risk to humans who may consume them. All of the currently registered contraceptives have been thoroughly evaluated by the appropriate regulatory agency and have been found to pose minimal risk to target or non-target species, humans or to the environment.

The public is increasingly requesting the use of nonlethal techniques when managing wildlife, including contraceptives, and communities are sometimes willing to fund reproductive control of wildlife populations. Wildlife agencies and biologists have been reluctant to acknowledge the potential applicability of fertility control for managing wildlife populations, in part because fertility control has been publicized as a replacement for sport hunting. In reality, neither the cost nor efficiency of delivery for contraceptive techniques would allow their use on free-ranging game populations outside urban areas. However, wildlife management agencies are increasingly willing to view fertility control as an alternative to other management tools for non-game species and for game species in areas where hunting is restricted. The challenges for wildlife managers will be to integrate contraceptive technologies with more conventional methods of wildlife population management.

\section{REFERENCES}

Adams TE, Adams BM (1992). Feedlot performance of steers and bulls actively immunized against gonadotropin-releasing hormone. Journal of Animal Science 70,
691-8.

Andrews RV, Belknap RW (1983). Efficacy of alpha?-chlorohydrin in sewer rat control. Journal of Hygiene 91, 359-66.

Asa CS (1997). The development of contraceptive methods for captive wildlife. In: Kreeger TJ, ed. USDA-APHIS Technical Bulletin 1853. Washington, DC, USA, pp. 23540.

Asa CS, Zaneveld LJD, Munson L et al. (1996). Efficacy, safety and reversibility of a bisdiamine as a male-directed oral contraceptive in gray wolves (Canis lupus). Journal of Zoo and Wildlife Medicine 27, 501-6.

Aspden WJ, Rao A, Scott PT et al. (1996). Direct actions of the luteinizing hormone-releasing hormone agonist, deslorelin, on anterior pituitary contents of luteinizing hormone (LH) and follicle-stimulating hormone (FSH), LH and FSH subunit messenger ribonucleic acid, and plasma concentrations of LH and FSH in castrated male cattle. Biology of Reproduction 55, 386-92.

Asquith KL, Kitchener AL, Kay DJ (2006). Immunisation of the male tammar wallaby (Macropus eugenii) with spermatozoa elicits epididymal antigen-specific antibody secretion and compromised fertilisation rate. Journal of Reproductive Immunology 69, 127-47.

Avery ML, Lindsay JR, Newman JR, Pruett-Jones S, Tillman EA (2006). Reducing monk parakeet impacts to electric utility facilities in South Florida. In: Feare CJ, Cowan DP, eds. Advances in Vertebrate Pest Management, Vol. IV. Filander Verlag. Furth, Federal Republic of Germany, pp. 125-36.

Aydin R, Cook ME (2006). Dietary conjugated linoleic acid to control the population of wild bird species considered a pest. Journal of Wildlife Management 70, 17868.

Baker DL, Nett TM, Hobbs NT, Gill RB, Miller MM (1999). Evaluation of GnRH-toxin conjugate as an irreversible contraceptive in female mule deer. The Wildlife Society $6^{\text {th }}$ Annual Conference; 5-11 Sep 1999, Austin, Texas, USA, The Wildlife Society, p. 61.

Baker DL, Wild MA, Conner MM, Hussain MD, Dunn RL, Nett TM (2003). Evaluation of leuprolide as a contraceptive agent in free-ranging elk: a feasibility experiment. Colorado Division of Wildlife, Federal Aid to Wildlife Restoration, Project W-153-R-12, Fort Collins, Colorado, USA.

Baker DL, Wild MA, Conner MM, Ravivarapu HB, Dunn RL, Nett TM (2002). Effects of GnRH agonist (leuprolide) on reproduction and behavior in female wapiti. Reproduction Supplement 60, 155-67. 
Baker DL, Wild MA, Conner MM, Ravivarapu HB, Dunn RL, Nett TM (2004). Gonadotropin releasing hormone agonist: a new approach to reversible contraception in female deer. Journal of Wildlife Diseases 40, 713-24.

Baker DL, Wild MA, Hussain MD, Dunn RL, Nett TM(2005). Evaluation of remotely delivered leuprolide acetate as a contraceptive agent in female elk (Cervus elaphus nelsoni). Journal of Wildlife Diseases 41, 758-67.

Barr JJF, Lurz PWW, Shirley MDF, Rushton SP (2002). Evaluation of immunocontraception as a publicly acceptable form of vertebrate pest species control: The introduced grey squirrel in Britain as an example. Environmental Management 30, 342-51.

Becker SE, Katz LS (1995). Effects of Gonadotropin-releasing hormone agonist on serum LH concentrations in female white-tailed deer. Small Ruminant Research 18, 145-50.

Bell RL, Peterle TJ (1975). Hormone implants control reproduction in white-tailed deer. Wildlife Society Bulletin $\mathbf{3}$, 52-156.

Bennett K (1993). Compendium of Beef Products. North American Compendiums, Port Huron, Michigan, USA.

Bergfeld E, D’Occhio MJ, Kinder JE (1996). Pituitary function, ovarian follicular growth, and plasma concentrations of 17 á-oestradiol and progesterone in prepubertal heifers during and after treatment with the luteinizing hormone-releasing hormone agonist deslorelin. Biology of Reproduction 54, 776-82.

Bomford M (1990). A role for fertility control in wildlife management? Bureau of Rural Resources, Bulletin Number 7, Australian Government Publishing Service, Canberra, Australia.

Bowerman AM, Brooks JC (1971). Evaluation of U-5897 as a male chemosterilant for rat control. Journal of Wildlife Management 35, 618-24.

Bradley MP (1997). Immunocontraceptive vaccines for control of fertility in the European red fox (Vulpes vulpes). In: Kreeger TJ, ed. Contraception in Wildlife Management. USDA-APHIS Technical Bulletin 1853, Washington, DC, USA, pp. 195-203.

Brown JL, Jochle W (2001). Use of deslorelin to suppress estrous cyclicity in elephants: importance of endocrine monitoring to assess efficacy. In: Bertschiniger HJ, Kirkpatrick JF, technical coordinators. Proceedings of the 5 th International Symposium on Fertility Control in Wildlife; 19-22 Aug 2001, Kruger National Park, South Africa, pp. 20-1.

Bynum KS, Yoder CA, Eisemann JD, Johnston JJ, Miller
LA (2005). Development of nicarbazin as a reproductive inhibitor for resident Canads geese. Wildlife Damage Management Conference 11, 179-89.

Bynum KS, Eisemann JD, Weaver GC, Yoder CA, Fagerstone KA, Miller LA (2007). Nicarbazin OvoControl $\mathrm{G}$ bait reduces hatchability of eggs laid by resident Canada geese in Oregon. Journal of Wildlife Management 71, 135-43.

Chang CLT, Fung HP, Lin YF, Iwo CY, Chien CW (2002). Indenopyridine hydrochloride induced testicular spermatogenesis failure with high seminal alkaline phosphatase levels in male dogs. Biological and Pharmaceutical Bulletin 25, 1097-100.

Chin SF, Strokson JM, Albright KJ, Cook ME, Pariza MW (1994). Conjugated linoleic acid is a growth factor for rats as shown by enhanced weight gain and improved feed efficiency. Journal of Nutrition 124, 2344-9.

Cooney B (1995). The evolution of a multipurpose molecule. In: 1995 Science Report, College of Agriculture and Life Sciences. University of Wisconsin, Madison, WI, USA, pp. 30-3.

Curtis PD, Decker DJ, Stout RJ, Richmond ME, Loker CA (1997). Human dimensions of contraception in wildlife management. In: Kreeger TJ, ed. Contraception in Wildlife Management. USDA-APHIS Technical Bulletin 1853. Washington, DC, USA, 247-55.

DeLiberto TJ, Gese EM, Knowlton FF et al. (1998). Fertility control in coyotes: Is it a potential management tool? Vertebrate Pest Conference 18, 144-9.

DeNicola AJ, Kesler DJ, Swihart RK (1997a). Dose determination and efficacy of remotely delivered norgestomet implants on contraception of white-tailed deer. Zoo Biology 16, 31-7.

DeNicola AJ, Kesler DJ, Swihart RK (1997b). Remotely delivered prostaglandin $\mathrm{F}_{2}$ implants terminate pregnancy in white-tailed deer. Wildlife Society Bulletin 25, 52731.

D’Occhio MJ, Aspden WJ, Whyte TR (1996). Controlled, reversible suppression of oestrous cycles in beef heifers and cows using agonist of luteinizing hormone-releasing hormone. Journal of Animal Science 74, 21825.

D’Occhio MJ, Fordyce G, Whyte TR et al. (2002). Use of GnRH agonist implants for long-term suppression of fertility in extensively managed heifers and cows. Animal Reproduction Science 74, 151-62.

Dolbeer RA (1998). Population dynamics: The foundation of wildlife damage management for the 21 st century. 
Vertebrate Pest Conference 18, 2-11.

Drell DD, Wood DM, Bundman D, Dunbar BS (1984). Immunological comparison of antibodies to porcine zonae pellucidae in rats and rabbits. Biology of Reproduction 30, 435-44.

Dunbar BS (1989). Use of a synthetic peptide adjuvant for the immunization of baboons with denatured and deglycosylated pig zona pellucida glycoproteins. Fertility and Sterility 52, 311-8.

Dunbar BS, Schwoebel E (1988). Fertility studies for the benefit of animals and human beings: Development of improved sterilization and contraceptive methods. Journal of the American Veterinary Medical Association 193, 1165-70.

Eason CT, Fagerstone KA, Eisemann JD, Humphreys S, O'Hare JR, Lapidge SJ (2010). A review of existing and potential new world vertebrate pesticides with a rationale for linking use patterns to registration requirements. International Journal of Pest Management (in press).

Ericsson RJ (1982). Alpha-chlorohydrin (Epibloc): A toxicant-sterilant as an alternative in rodent control. Vertebrate Pest Conference 10, 6-9.

Fagerstone KA, Coffey MA, Curtis PD et al. (2002). Wildlife fertility control. The Wildlife Society Technical Review 02-2, 29 pp.

Fraker MA, Brown RG, Gaunt GE, Kerr JA, Pohajdak B (2002). Long-lasting, single-dose immunocon-traception of feral fallow deer in British Columbia. Journal of Wildlife Management 66, 1141-7.

Garrott RA (1995). Effective management of free-ranging ungulate populations using contraception. Wildlife Society Bulletin 32, 445-52.

GarrottRA, SiniffDB, Tester JR, Eagle TC, Plotka ED(1992). A comparison of contraceptive technologies for feral horse management. Wildlife Society Bulletin 20, 31826.

Herbert C, Trigg TE (2005). Applications of GnRH in the control and management of fertility in female animals. Animal Reproduction Science 66, 141-53.

Hobbs NT, Bowden DC, Baker DL (2000). Effects of fertility control on populations of ungulates: general, stagestructured models. Journal of Wildlife Management 64, 473-91.

Hu X, Roberts JR, Apopa PL, Kan YW (2006). Accelerated ovarian failure induced by 4-vinyl cyclohexene diepoxide in Nrf2 null mice. Molecular and Cellular Biology 26, $940-54$.

Jacobson NK, Jessup DA, Kesler DJ (1995). Contraception in black-tailed deer by remotely delivered norgestomet ballistic implants. Wildlife Society Bulletin 23, 718-22.

Jagadish N, Rana R, Mishra D, Garg M, Selvi R, Suri A (2006). Characterization of immune response in mice to plasmid DNA encoding human sperm associated antigen 9 (SPAG9). Vaccine 24, 3695-703.

Jewgenow K, Rohleder M, Wegner I (2000). Differences between antigenic determinants of pig and cat zona pellucida proteins. Journal of Reproductive Fertility 119, $15-23$.

Jones JE, Solis J, Hughes BL, Castaldo DJ, Toler JE (1990). Production and egg quality responses of white leghorn layers to anticoccidial agents. Poultry Science 69, 37887.

Kazensky CA, Munson L, Seal US (1998). The effects of melengestrol acetate on the ovaries of captive wild felids. Journal of Zoo and Wildlife Medicine 29, 1-5.

Killian GJ, Miller LA (2000). Behavioral observations and physiological implications for white-tailed deer treated with two different immunocontraceptives. Wildlife Damage Management Conference 9, 283-91.

Killian G, Miller LA, Rhyan J, Dees T, Doten H(2003). Evaluation of GnRH contraceptive vaccine in captive feral swine in Florida. Wildlife Damage Management Conference 10, 128-33.

Killian G, Miller LA, Diehl NK, Rhyan J, Thain D (2004). Evaluation of three contraceptive approaches for population control of wild horses. Vertebrate Pest Conference 21, 263-8.

Killian G, Eisemann J, Wagner D et al. (2006a). Safety and toxicity evaluation of GonaCon immunocontraceptive vaccine in white-tailed deer. Vertebrate Pest Conference 22, 82-7.

Killian G, Miller LA, Diehl NK, Rhyan J, Thain D (2006b). Long-term efficacy of three contraceptive approaches for population control of wild horses. Vertebrate Pest Conference 22, 67-71.

Killian G, Miller L, Rhyan J, Doten H (2006c). Immunocontraception of Florida feral swine with a single-dose GnRH vaccine. American Journal of Reproductive Immunology 55, 378-84.

Kirkpatrick JF, Liu IKM, Turner JW (1990). Remotely-delivered immunocontraception in feral horses. Wildlife Society Bulletin 18, 326-30.

Knipling EF, McGuire JU (1972). Potential role of sterilization for suppressing rat populations, a theoretical appraisal. Technical Bulletin Number 1455, Agricultural Research Service. United States Department of 
Agriculture, Washington, DC, USA.

Konig, A (2008). Fears, attitudes and opinions of suburban residents with regards to their urban foxes. European Journal of Wildlife Research 54, 101-9.

Lapidge S, Humphrys S, Dall S (2007). Global harmonisation in the field of invasive species management product development. In: Witmer GW, Pitt WC, Fagerstone KA, eds. Managing Vertebrate Invasive Species: Proceedings of the International Symposium; 7-9 Aug 2007, Fort Collins, CO, USA. USDA APHIS Wildlife Services, pp. 34-41.

Levy JK, Miller LA, Cynda PC, Ritchey JW, Ross MK, Fagerstone KA (2004). GnRH immunocontraception of male cats. Theriogenology 62, 1116-30.

Lofts B, Murton RK, Thearle JP (1968). The effects of 22, 25 diazacholesterol dihydrochloride on the pigeon testis and reproductive behavior. Journal of Reproduction and Fertility 15, 145-8.

Mahi-Brown CA, Yanagimachi R, Hoffman JC, Huang, Jr TTF (1985). Fertility control in the bitch by active immunization with porcine zonae pellucidae: Use of different adjuvants and pattern of estradiol and progesterone levels in estrous cycles. Biology of Reproduction 32, 76172.

Matschke GH (1977). Antifertility action of two synthetic progestins in female white-tailed deer. Journal of Wildlife Management 41, 731-5.

Mayer LP (2006). Chemical acceleration of ovarian senescence: ACAOS strategy! Proceedings of the Third International Symposium on Non-Surgical Contraception Methods for Pet Population Control. Alliance for Contraception in Cats and Dogs; 9-12 Nov 2006, Alexandria, VA.

Mayer LP, Devine PJ, Dyer CA, Hoyer PB (2004). The follicle-deplete mouse ovary produces androgen. Biology of Reproduction 71, 130-8.

McCauley AP, Geller JS (1992). Decisions for Norplant programs. In: Goldstein SM, ed. Population Reports, series K, Number 2. Johns Hopkins University, Population Information Program, Baltimore, Maryland, USA, p 31.

McCullough DR (1996). Demography and management of wild populations by reproductive intervention. In: Cohn PN, Plotka ED, Seal US, eds. Contraception in wildlife. The Edwin Mellen Press, Lewiston, NY. pp. 119-32.

McDonald M (1980). Population control of feral cats using megestrol acetate. Veterinary Record 109, 129.

McShea WJ, Monfort SL, Hakim S et al. (1997). The effect of immunocontraception on the behavior and reproduction of white-tailed deer. Journal of Wildlife Management 61, 560-9.

Merrill JA, Cooch EG, Curtis PD (2006). Managing an overabundant deer population by sterilization: Effects of immigration, stochasticity and the capture process. Journal of Wildlife Management 70, 268-77.

Middleton AD (1930). Ecology of the American gray squirrel in the British Isles. Proceedings of the Zoological Society of London 1930, 809-43.

Miller LA (1995). Immunocontraception as a tool for controlling reproduction in coyotes. In: Coyotes in the Southwest: A Compendium of Our Knowledge. Texas Parks and Wildlife Department, San Angelo, Texas, USA, pp. 172-6.

Miller LA, Fagerstone KA (2000). Induced infertility as a wildlife management tool. Vertebrate Pest Conference 19, 160-8.

Miller LA, Killian GJ (2000). Seven years of white-tailed immunocontraception research at Penn State University: A comparison of two vaccines. Wildlife Damage Management Conference 9, 60-9.

Miller LA, Killian GJ (2002). In search of the active PZP epitope in white-tailed deer immunocontraception. Vaccine 20, 2735-42.

Miller LA, Johns BE, Elias DJ, Crane KA (1997). Comparative efficacy of two immunocontraceptive vaccines. Vaccine 15, 1858-62.

Miller LA, Johns BE, Killian GJ (2000a). Immunocontraception of white-tailed deer using native and recombinant zona pellucida vaccines. Animal Reproduction Science 63, 87-195.

Miller LA, Johns BE, Killian GJ (2000b). Long-term effects of PZP immunization on reproduction in white-tailed deer. Vaccine 18, 568-74.

Miller LA, Johns BE, Killian GJ $(2000 \mathrm{c})$. Immunocontraception of white-tailed deer with $\mathrm{GnRH}$ vaccine. American Journal of Reproductive Immunology 44, 266-74.

Miller LA, Crane K, Gaddis S, Killian GJ (2001). Porcine zona pellucida immunocontraception: Long-term health effects on white-tailed deer. Journal of Wildlife Management 65, 941-5.

Miller L, Rhyan J, Killian G (2003). Evaluation of GnRH contraceptive vaccine using domestic swine as a model for feral hogs. Wildlife Damage Management Conference 10, 120-7.

Miller LA, Rhyan JC, Drew M (2004a). Contraception of 
bison by GnRH vaccine: A possible means of decreasing transmission of brucellosis in bison. Journal of Wildlife Diseases 40, 725-30.

Miller LA, Rhyan J, Killian G. (2004b). GonaCon ${ }^{(\mathrm{TM})}$ : A versatile GnRH contraceptive for a large variety of pest animal problems. Vertebrate Pest Conference Proceedings 21, 269-73.

Miller LA, Bynum KS, Zemlicka D (2006). PZP immunocontraception in coyotes: A multi-year study with three vaccine formulations. Vertebrate Pest Conference 22, 88-95.

Morell V (1993). Australian pest control by virus causes concern. Science 261, 683-4.

Nash PB, James DK, Hui L, Miller LA (2004). Fertility control of California ground squirrels using GnRH immunocontraception. Vertebrate Pest Conference 21, 274-8.

Naz RK (2006). Effect of sperm DNA vaccine on fertility of female mice. Molecular Reproduction and Development 73, 918-28.

Nett TM, Crowder ME, Moss GE, Duello TM(1981). GnRHreceptor interaction. V. Down-regulation of pituitary receptors for $\mathrm{GnRH}$ in ovariectomized ewes by infusion of homologous hormone. Biology of Reproduction 24, 1145-55.

Nielsen CK, Porter WF, Underwood HB (1997). An adaptive management approach to controlling suburban deer. Wildlife Society Bulletin 25, 470-7.

Plotka ED, Seal US (1989). Fertility control in female whitetailed deer. Journal of Wildlife Diseases 25, 643-6.

Pochop PA, Cummings JL, Steuber JE, Yoder CA (1998). Effectiveness of several oils to reduce hatchability of chicken eggs. Journal of Wildlife Management 62, 395-8.

Ravivarapu HB, Moyer KL, Dunn RL (2000). Sustained activity and release of leuprolide acetate from an in situ forming polymeric implant. American Association of Pharmaceutical Scientist 1, 1-12.

Roughton RD (1979). Effects of oral melengestrol acetate on reproduction in captive white-tailed deer. Journal of Wildlife Management 43, 428-36.

Sachs BA, Wolfmann L (1965). 20,25-Diazacholesterol Dihydrochloride. Archives of Internal Medicine 116, 366-72.

Sanborn WA, Schmidt RH, Freeman HC (1994). Policy considerations for contraception in wildlife management. Vertebrate Pest Conference 16, 311-6.

Seagle SW, Close JD (1996). Modeling white-tailed deer Odocoileus virginianus population control by contraception. Biological Conservation 76, 87-91.

Springer L, Flaws NJA, Sipes IG, Hoyer PB (1996). Follicular mechanisms associated with 4-vinylcyclohexene diepoxide-induced ovotoxicity in rats. Reproductive Toxicology 10, 137-43.

Talwar GP, Gaur A (1987). Recent developments in immunocontraception. American Journal of Obstetrics and Gynecology 157, 1075-8.

Trigg TE, Doyle AG (2001). A long-acting GnRH analogue implant for the postponement of oestrus and prevention of spermatogenesis. In: Bertschinger HJ, Kirkpatrick JF, technical coordinators. Proceedings of the 5th International Symposium on Fertility Control in Wildlife; 19-22 Aug 2001, Kruger National Park, South Africa, pp.70-1.

Turner JW, Kirkpatrick JF (1991). New developments in feral horse contraception and their potential application to wildlife. Wildlife Society Bulletin 19, 350-9.

Turner JW, Liu IKM, Kirkpatrick JF (1992). Remotely delivered immunocontraception in white-tailed deer. Journal of Wildlife Management 56, 154-7.

Turner JW, Liu IKM, Kirkpatrick JF (1996). Remotely delivered immunocontraception in free-roaming feral burros (Equus asinus). Journal of Reproduction and Fertility 107, 31-5.

Turner JW, Kirkpatrick JF, Liu IKM (1997). Immunocontraception in white-tailed deer. In: Kreeger TJ, ed. Contraception in Wildlife Management. USDAAPHIS Technical Bulletin 1853, Washington, DC, USA, pp. 142-59.

Turner JW, Liu IKM, Flanagan DR, Rutberg AT, Kirkpatrick JF (2000). Immunocontraception in feral horses: A single inoculation vaccine providing one year of infertility. Journal of Wildlife Management 65, 235-41.

Turner JW, Liu IKM, Flanagan DR, Bynum KS, Rutberg AT (2002). Porcine zona pellucida (PZP) immunocontraception of wild horses (Equus caballus) in Nevada: A 10-year study. Reproduction 60, 177-86.

Turner JW, Liu IKM, Flanagan DR, Rutberg AT, Kirkpatrick JF (2007). Immunocontraception in wild horses: one inoculation provides two years of infertility. Journal of Wildlife Management 71, 662-7.

Tyndale-Biscoe CH (1991). Fertility control in wildlife. Reproduction Fertility and Development 3, 339-43.

Waddell RB, Osborn DA, Warren RJ, Griffin JC, Kesler DJ (2001). Prostaglandin F2?-mediated fertility control in captive white-tailed deer. Wildlife Society Bulletin 29, 1067-74. 
Warren RJ (1995). Should wildlife biologists be involved in wildlife contraception research and management? Wildlife Society Bulletin 23, 441-4.

Warren RJ, Fayrer-Hosken RA, White LM, Willis LP, Goodloe RB (1997). Research and field applications of contraceptives in white-tailed deer, feral horses and mountain goats. In: Kreeger TJ, ed. Contraception in Wildlife Management. USDA-APHIS Technical Bulletin 1853, Washington, DC, USA, pp. 133-45.

White LM, Warren RJ, Fayrer-Hosken RA (1994). Levonorgesterel implants as a contraceptive in captive white-tailed deer. Journal of Wildlife Diseases 30, 241-6.

Wildlife Services (2004). Multi-center field study of nicarbazin bait for use in the reduction of hatching of eggs laid by local Canada goose flocks. Environmental Assessment. USDA-APHIS-WS-NWRC, Fort Collins,
$\mathrm{CO}, 67 \mathrm{pp}$.

Woulfe MR (1968). Chemosterilants and bird control. Proceedings of the Bird Control Seminar 4, 146-52.

Yoder C (2000). Use of 20,25 diazacholesterol, AGnRH, and cRCP to inhibit reproduction in Coturnix quail (Thesis). Colorado State University, Fort Collins, Colorado, USA.

Yoder CA, Andelt WF, Miller LA, Johnston JJ, Goodall MJ (2004). Effectiveness of twenty, twenty-five diazacholesterol, avian gonadotropin-releasing hormone, and chicken riboflavin carrier protein for inhibiting reproduction in Coturnix quail. Poultry Science 83, 234-44.

Zimbelman RG, Smith LW (1966). Control of ovulation in cattle with melengestrol acetate. I. Effect of dosage and route of administration. Journal of Reproduction and Fertility 11, 185-91. 